\title{
Reabilitação e melhoria ambiental em edifícios de grande porte organizados em galeria
}

\section{Rehabilitation and environmental improvement in large gallery buildings}

Prof. Dr. Teresa Madeira Silva

Instituto Superior de Ciencia do Trabalho e da Empresa Instituto Universitario de Lisboa (ISCTE-IUL), Lisboa,

Portugal. Contato:teresa.madeira@iscte.pt

Prof. Dr. Vasco Moreira Rato

Instituto Superior de Ciencia do Trabalho e da Empresa Instituto Universitario de Lisboa (ISCTE-IUL), Lisboa,

Portugal . Contato: vasco.rato@iscte.pt

Pedro Marques Alves

Faculdade de ciencias sociais e humanas - Universidade Nova Lisboa (FCSH-UNL), Lisboa, Portugal. Contato: p.marques.alves@gmail.com

\section{Abstract}

This paper is the result of a study evaluate and diagnose the need to intervene in two social housing complexes (known as "J Zone" and "Pink Panther Pink"), located in Marvila (Chelas) in the city of Lisbon, undertaken by a team from ISCTE Lisbon University Institute, for the IHRU (Housing and Urban Rehabilitation Institute).

These are housing neighborhoods which were designed and built in the 1970 s and 1980s. They are social housing quarters organized into gallery and built at a time when the regulations about environmental issues and security were relatively bland. Nowadays we can find them very deteriorated, with major security problems and serious pathologies in relation to energy and environmental conditions.

The focus of this paper relates to a set of questions related to the typological and constructive solutions of these issues sets, once we considered that both can contribute to environmental and functional improvement of the entire building. On the one hand, we seek to meet current building regulations and the real needs of those who live there, on the other hand we seek that the possible solutions ensure the assumptions of clear quality of the original project.

The answers to the raised questions ultimately take the form of concrete proposals, through spatial reorganization of the set, and from the identification of the causes and solutions to the identified pathologies.

Keywords: collective housing; regeneration; public space, urban regeneration; gallery buildings.
Miguel Vasconcelos Magalhães

Instituto Superior de Ciencia do Trabalho e da Empresa Instituto Universitario de Lisboa (ISCTE-IUL), Lisboa, Portugal

Contato: miguel.v.magalhaes@gmail.com

Maria João de Oliveira

Instituto Superior de Ciencia do Trabalho e da Empresa Instituto Universitario de Lisboa (ISCTE-IUL), Lisboa, Portugal

Contato: mjoaomoliveira@gmail.com

\section{Resumo}

Este artigo decorre de um estudo de avaliação e diagnóstico das necessidades de intervenção em dois bairros sociais, (a "Zona J" e a "Pantera Corde-rosa"), situados em Marvila (Chelas), na cidade de Lisboa, realizado por uma equipa do ISCTE - Instituto Universitário de Lisboa, para o IHRU - Instituto de Habitação e Reabilitação Urbana.

Os edifícios de habitação colectiva em estudo foram projectados e construídos nas décadas de 70 e 80 do século XX. São bairros de habitação social organizados em galeria, construídos numa época em que a regulamentação vigente, acerca das questões ambientais e de segurança, era relativamente branda. Podemos hoje encontralos muito deteriorados, com grandes problemas de segurança, e graves patologias em relação às condições energéticas e ambientais.

$\mathrm{O}$ enfoque deste artigo prende-se com um conjunto de questões relacionadas com as soluções tipológicas e os aspetos construtivos destes conjuntos, uma vez que consideramos que ambos podem contribuir para a melhoria funcional e ambiental de todo o edificado. Por um lado, procuramos atender às actuais normas regulamentares da edificação e às necessidades reais de quem lá habita, por outro, procuramos que as soluções possíveis ressalvassem os pressupostos de qualidade inequívoca do projecto original. As respostas às questões levantadas acabaram por assumir a forma de propostas concretas, através da reorganização espacial do conjunto, e a partir da identificação das causas e das soluções encontradas para as patologias identificadas.

Palavras-chave: habitação colectiva; reabilitação; espaço público, reabilitação urbana; edifícios em galeria. 


\section{Introdução}

Este artigo ${ }^{i}$ decorre de um estudo de avaliação e diagnóstico das necessidades de intervenção em dois bairros sociais, situados em Marvila (Chelas), na cidade de Lisboa, realizado por uma equipa do Instituto Universitário de Lisboa, ISCTE-IULii, para o IHRU Instituto de Habitação e Reabilitação Urbana. No essencial, o estudo resulta num "instrumento de apoio à decisão" que serve as entidades responsáveis - o Gabinete Viver Marvila do Instituto da Habitação e da Reabilitação Urbana (IHRU) e a Câmara Municipal de Lisboa (CML) - sobre o futuro dos bairros em causa. Tendo sido elaborado, na conclusão do estudo, um Relatório Final, este artigo centra-se nos aspectos da reabilitação que contribuem para a melhoria das condições ambientais dos conjuntos edificados, nomeadamente as soluções tipológicas e as questões construtivasiii.

\section{Enquadramento}

Os dois conjuntos urbanos, situados na zona oriental da cidade de Lisboa, na freguesia de Marvila e apelidados de "Zona J" e "Pantera Cor-deRosa”, foram construídos após a revolução de Abril de 1974 com o intuito de alojar principalmente população que vivia em barracas, nestas e noutras zonas da cidade, e retornados das ex-colónias. A construção da maioria destes bairros correspondeu à resposta necessária a um problema quantitativo: o défice de habitação.

Decorridos cerca de 30 a 40 anos desde a sua construção, os conjuntos urbanos em estudo apresentam consideráveis níveis de deterioração, demonstrando indícios de inadequabilidade e proporcionando uma fraca qualidade de vida urbana quer em termos ambientais quer em termos de eficiência energética, segurança e conforto, decorrentes da qualidade construtiva. Correspondendo a uma importante percentagem do parque habitacional (entenda-se de habitação social), da cidade de Lisboa, revela-se primordial a necessidade de responder à questão qualitativa com que estes bairros agora se deparam.

Sendo bairros consideravelmente mediatizados, e cujas condições estariam em parte divulgadas, não deixamos de ser surpreendidos pela dimensão dos problemas com que somos confrontados logo a partir das primeiras visitas. A primeira impressão é de que, embora recentes (edificados na década de 1970 e de 1980), encontram-se num avançado estado de degradação construtiva, aspecto que forçosamente contribui directamente para a degradação da qualidade de vida dos seus habitantes.

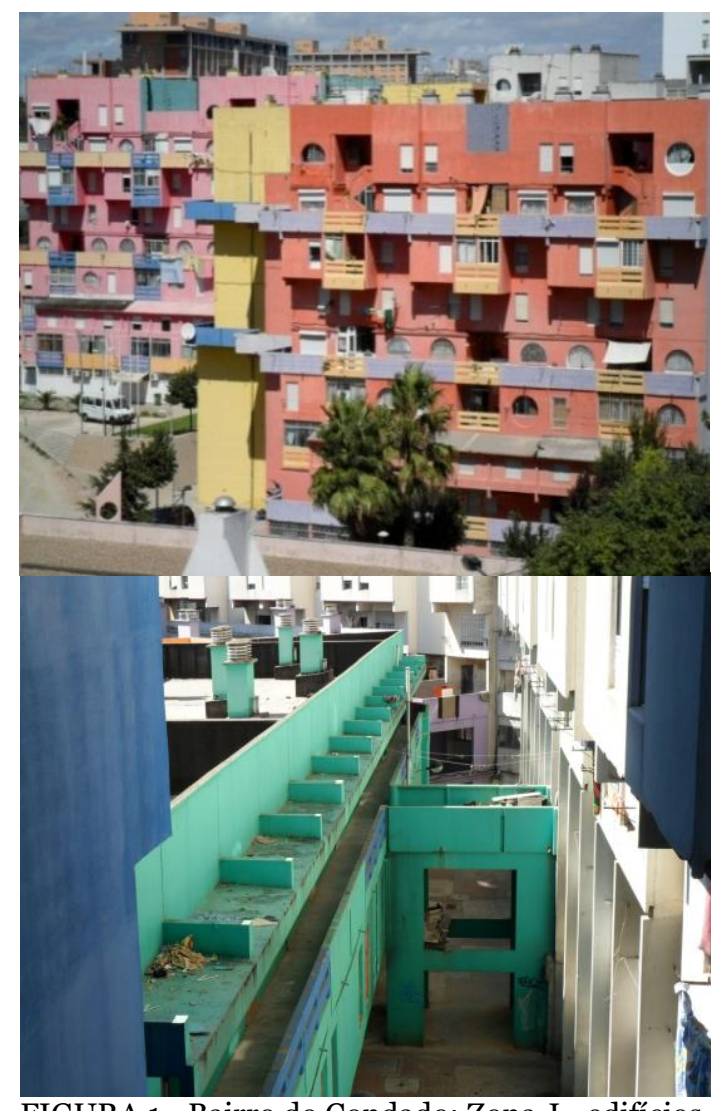

FIGURA 1 - Bairro do Condado: Zona J - edifícios em galeria. (Fotografias dos autores).

Em todos os conjuntos, desde o desenho do território à forma dos edifícios, verificamos princípios de organização espacial aparentemente pouco flexíveis na adaptação à população que neles habita e à evolução das suas necessidades correntes, assim como a adaptabilidade aos novos 
regulamentos (FIGs.1 e 2). Assim, a realidade construída traduz-se numa deficiente adaptação aos modos de vida actuais $\mathrm{e}$ às necessidades físicas $\mathrm{e}$ simbólicas dos residentes, concluindo-se que não constitui a resposta social, ambiental e urbana pretendida ou adequada.

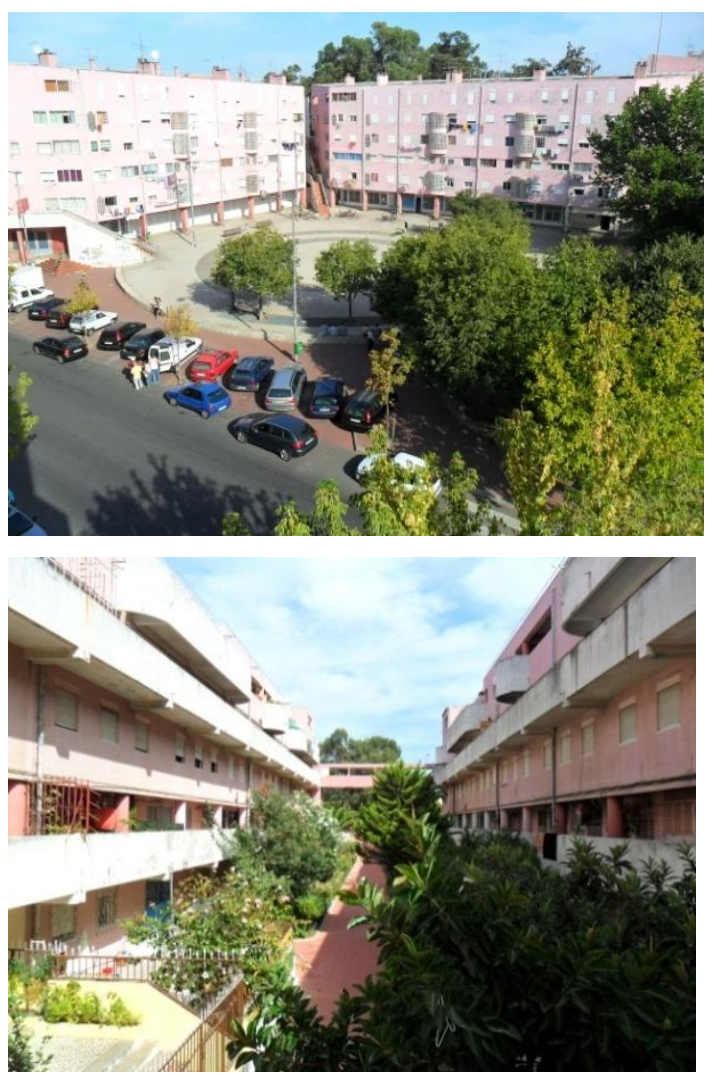

FIGURA 2 - Bairro dos Lóios: Pantera Cor-de-rosa ; Praça Raul Lino e edifícios em galeria. (Fotografias dos autores).

\section{Metodologia do estudo}

O estudo teve na sua base a recolha e o tratamento da informação disponível. Num primeiro momento, o acesso aos projectos originais dos conjuntos edificados tornou-se essencial para o arranque dos trabalhos. Assim, a partir da colaboração com o gabinete Viver Marvila foi possível aceder às cópias da documentação original dos projectos de arquitectura: em papel (da "Zona J") e, em formato digital (da "Pantera Cor-de-rosa") e cedido pelo Arquivo do Forte de Sacavém. Foi a partir deste material que se produziram as peças gráficas que serviram de base a todo trabalho de campo, levantamento e diagnóstico.

Também a revisão da literatura sobre as questões que um estudo desta natureza levanta foram essenciais para a persecução dos trabalhos. Em termos metodológicos, vários estudos serviram de referência para o desenvolvimento das questões construtivas e ambientais. O Relatório elaborado pelo LNEC acerca do parecer sobre anomalias nos revestimentos de fachada do bairro do Condado, em Chelas. (LNEC,2003), foi essencial para o aprofundar das questões sobre a reabilitação das fachadas do edificado, assim como a consulta de artigos sobre patologias da construção, nomeadamente (Silva e Abrantes, 2007), (Mendes da Silva, 2002), entre outros.

Num segundo momento, foram as reuniões alargadas com os serviços do IHRU, mais concretamente com a equipa técnica do gabinete "Viver Marvila" nas suas diferentes vertentes de trabalho, com os agentes e parceiros locais ${ }^{\text {iv }}$ e com os técnicos das várias especialidades incluídos na equipa de trabalho, nomeadamente de Fundações e Estruturas, Gestão Energética, Redes e Segurança Integrada (ver equipa nota 2), que permitiram a compreensão dos problemas e a avaliação das soluções adequadas.

De forma complementar, a informação cadastral e estatística existente permitiu aprofundar a caracterização do objecto em estudo. Por forma a registar a realidade encontrada a nível do edificado, procedeuse a um levantamento minucioso da situação existente. Equipas de técnicos visitaram todos os edifícios inscritos no limite do estudo e executaram, para além do levantamento fotográfico, o registo e mapeamento de alterações e anomalias em forma de peças gráficas. Com o levantamento efectuado, clarificaram-se as principais questões a abordar e o conjunto de patologias da construção tendo em perspetiva uma possível intervenção.

Com o intuito de operacionalizar a informação recolhida, procedeu-se ao 
tratamento e sistematização dos dados. Primeiramente, dividiu-se o objecto de estudo em parcelas e, de seguida, procedeu-se à elaboração de fichas de caracterização, tanto para o edificado, como para o espaço público. Esta forma de organização facilita a leitura e consulta da informação num universo de questões alargado e à partida pouco claro, uma vez que sistematiza e condensa os dados recolhidos. Relativamente ao levantamento do edificado, prestou-se especial atenção aos elementos directamente relacionados com a segurança, com as questões da habitabilidade, com a adequação aos usos, com a funcionalidade, com as questões de eficiência energética, com as acessibilidades, e com a relação com a envolvente próxima. Também se registou a forma de gestão do edificado, a identificação dos usos e do tipo de ocupação dos espaços públicos e de cada lote.

Assim, para cada lote, e em todos os edifícios, registaram-se, através do preenchimento de uma fichav, um conjunto de dados tais como: as características gerais (situação, composição em número de lotes, número de pisos e número de circulações verticais), os valores de proximidade, as tipologias, os acessos, a caracterização dos espaços intermédios (acessos, halls, pátios, galerias, corredores, terraços, etc.), o tipo de usos (habitação, comércio, serviços, restauração, lazer, edifícios religiosos, etc.), a composição construtiva, as patologias estruturais, e a acessibilidade às redes. Também as questões ambientais como a situação geográfica, a forma de assentamento no terreno, o tipo de protecção solar dos vãos, o aproveitamento passivo de energia, e os aspectos relativos à segurança contra incêndios, gestão dos edifícios e produtividade foram dados recolhidos e registados nas fichas de cada unidade funcional (AA.vv., 2011).

Dado que a tipologia dos diferentes lotes e unidades habitacionais, bem como a distribuição de funções e a forma das circulações, também podem influenciar a melhoria das condições ambientais do edificado, estas foram igualmente levantadas e registadas. Foram alvo de levantamento, e registados em desenho, os usos e o tipo de ocupação, os condicionamentos de circulação, os tipos de pavimento (instalados posteriormente nas partes comuns dos lotes), a relação com a rua (ao nível do piso térreo, já que define a relação primeira do edificio com a sua envolvente), o sistema de combate a incêndio e o estado de conservação das diferentes redes (electricidade, água, gás e sistema de iluminação existentes nas partes comuns). Foram igualmente identificados as ocupações do espaço comum (anexos, telheiros, ou similares), e o tipo de cobertura de cada lote (que adquire especila importância para 0 desempenho energético da construção). Foi dada especial atenção aos aspectos relacionados com os acessos e sistemas de circulação (relação entre o espaço público e os fogos), uma vez que aqui se interfere directamente com a segurança dos moradores e com a capacidade de resposta do edifício em caso de necessidade de fuga.

\section{Forma construída e qualidade construtiva}

Colocou-se um conjunto de questões-chave que serviram de orientação à realização do diagnóstico (AA.vv., 2011: 5. Diagnóstico). Questões relacionadas com os aspectos urbanos (que não nos interessam referir neste artigo) e questões directamente relacionadas com 0 edificado. 

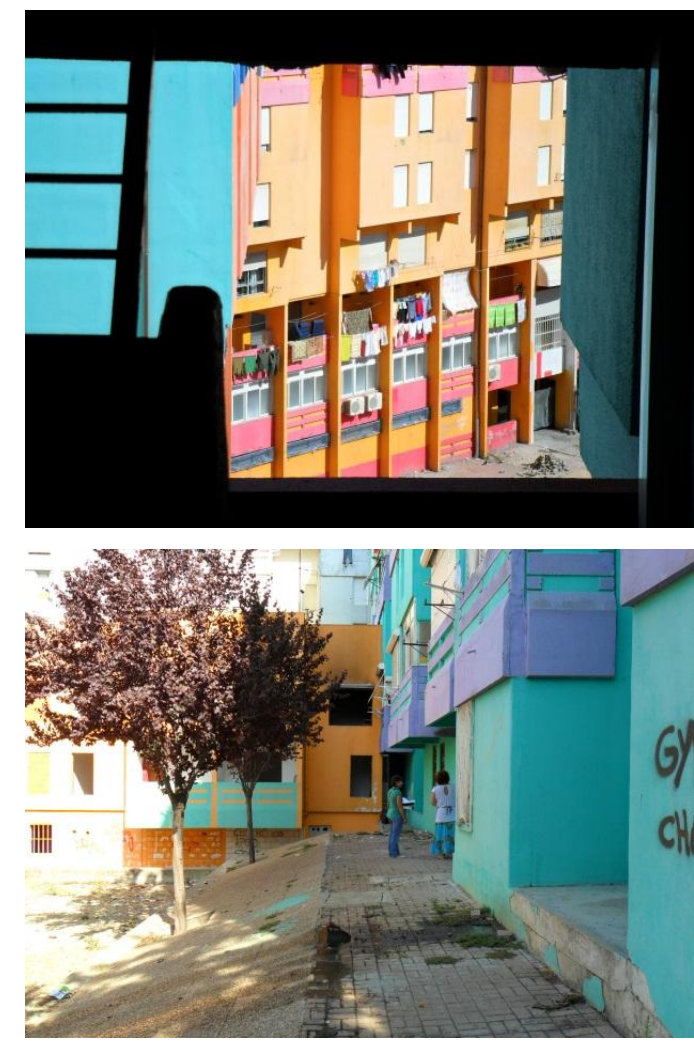

FIGURA 3 - Bairro do Condado: Zona J. (Fotografias dos autores).

Assim, a forma construída dos conjuntos em estudo, e a sua qualidade construtiva, são as duas questões no estudo que realizamos, consideradas relevantes no que se refere ao conforto ambiental e melhoria das condições de habitabilidade dos conjuntos.

Relativamente à primeira questão: a forma construída dos conjuntos em estudo, podemos verificar que esta cria obstáculos aos modelos de governabilidade, uma vez que não existe definição das fronteiras entre lotes (FIG. 3). Deste modo, a partilha de espaços de circulação entre habitantes de diferentes lotes, se por um lado, proporciona situações de convivência salutar, por outro é, muitas vezes, motivo e área de conflito para os moradores dos diferentes lotes ou fracções, potenciando e catalizando situações de apropriação de espaços comuns (e/ou públicos) e de encerramento e condicionamento de passagens no interior dos conjuntos edificados (FIG. 4). Esta situação contribui para a ausência ou deficiente manutenção dos espaços comuns de circulação bem como dos acessos, fachadas, coberturas, etc., acelarando a degradação do edifício e do ambiente. Por outro lado, verifica-se que a maioria dos lotes têm dependências comuns que obrigam à partilha dos mesmos acessos, das mesmas caixas de escadas, e dos mesmos elevadores, que constitui o principal obstáculo a uma gestão convencional dos edifícios estudados. Estes conjuntos de lotes (que partilham dependências essenciais ao funcionamento do edifício) receberam o nome de "unidades funcionais". Note-se que, dos 43 lotes estudados do Condado e dos 9 lotes estudados nos Lóios, apenas 11 e 5 , respetivamente, funcionam de forma isolada, portanto livres desta complexificação da gestão.

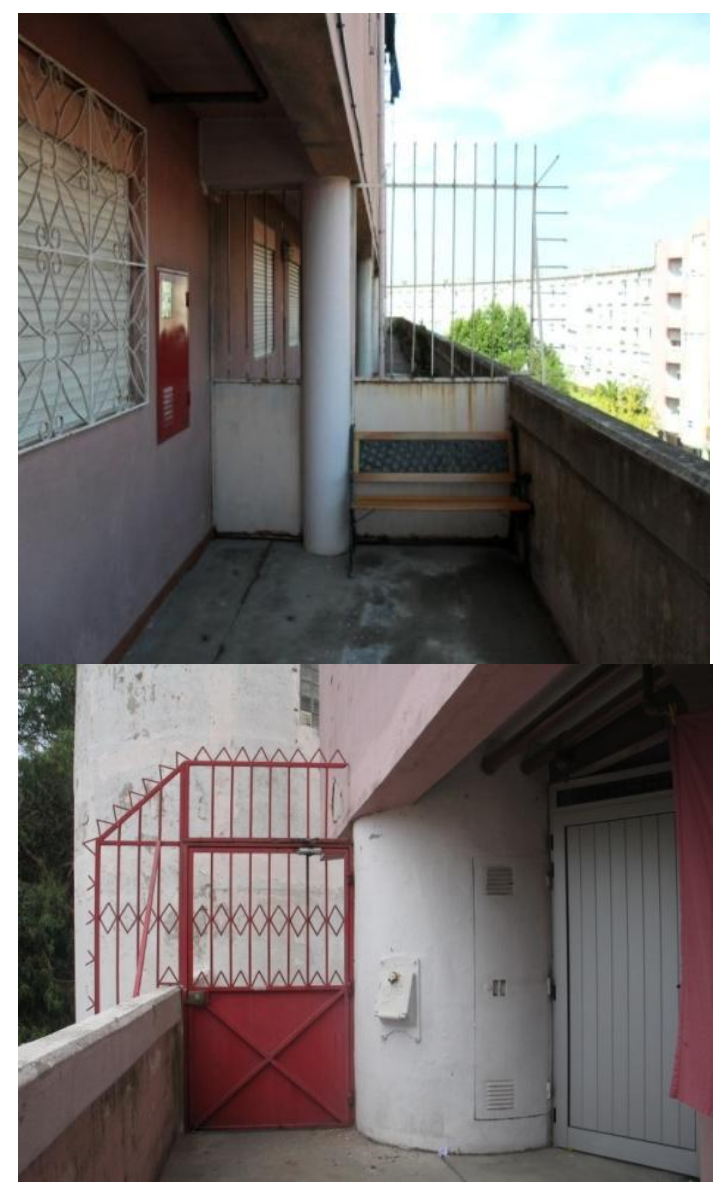

FIGURA 4 - Bairro dos Lóios: Pantera Cor-de-rosa. (Fotografias dos autores).

Às questões decorrentes da complexidade formal dos edifícios acresce uma outra decorrente da pouca clareza sobre a posição e papel que cabe a cada uma das entidades envolvidas na gestão 
deste património (IHRU, CML, administrações, associações de moradores, moradores, lojistas, etc.). Assim, em conformidade com a sua condição proprietários privados, proprietários públicos, arrendatários, ocupantes ilegais - cada um deles tem interesses e responsabilidades distintas que importam esclarecer.

Foi também diagnosticada a ausência geral de produtividade, ou seja, de meios que permitam criar receita para contribuir para a manutenção dos edifícios. Exceção feita para um dos lotes da "Pantera Cor-de-rosa", onde, mediante a "venda" do direito de utilização da cobertura, se registou a instalação de uma antena de telecomunicações móveis.

A segunda questão, - a qualidade construtiva, é importante, não só no que diz respeito às patologias do invólucro dos edifícios, à necessidade de consideração da segurança estrutural e do conforto dos habitantes, mas também porque a flexibilidade (ou falta dela), dos elementos construtivos condiciona a possibilidade de alteração da organização do espaço arquitetónico. Assim, importa identificar todas as patologias em paredes, coberturas e pavimentos e identificar numa primeira fase as suas causas, assim como, promover a flexibilização dos elementos construtivos, não só como resposta à organização arquitectónica, mas também como resposta à melhoria das condições de segurança, conforto e funcionamento. $\mathrm{Na}$ verdade, a nova regulamentação normativa força-nos a olhar para o património construído também segundo essa perspetiva. Se enquadrarmos os conjuntos em estudo no RCCTE (Regulamento das Características de Comportamento Térmico dos Edifícios), no Decreto-Lei 163/2006 (que aprova o regime de acessibilidade aos edifícios e estabelecimentos que recebem público), no Decreto-Lei 220/2008 (que estabelece o regime jurídico da segurança contra incêndios em edifícios), ou mesmo nas atualizações ao RGEU (Regulamento Geral de Edificações Urbanas), verificamos que será assinalável um considerável conjunto de deficiências.

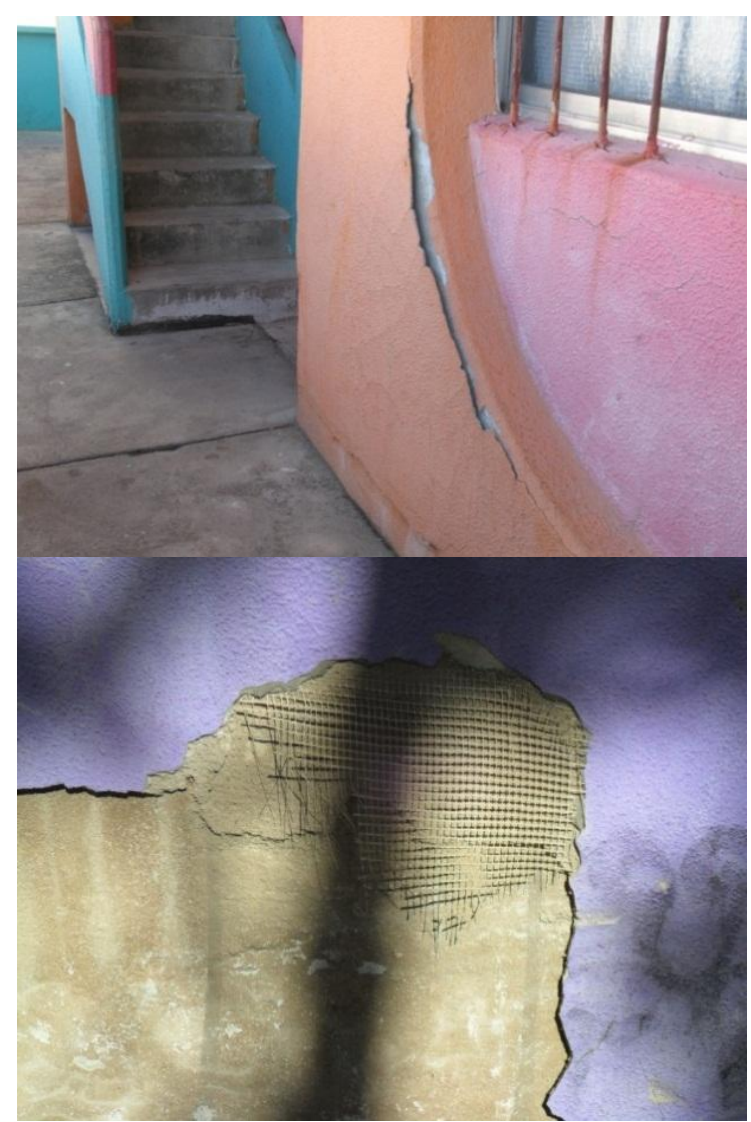

FIGURA 5 - Bairro do Condado: Zona J ; Patologias em paredes. (Fotografias dos autores).

No que diz respeito à qualidade construtiva dos edifícios, confirma-se a sua inequívoca degradação, que resulta de questões construtivas de projeto (permenorização construtiva), da idade do edificado associada à falta de manutenção, e também do modo (muitas vezes inadequado) como os utilizadores se apropriaram dos edifícios e seus espaços comuns. Existe todo um conjunto de patologias, que se podem observar in loco, que também foram consideradas em pormenor por um estudo do Laboratório Nacional de Engenharia Civil (LNEC: 2003), e que, em casos extremos, comprometem a segurança estrutural dos edifícios, sobretudo no bairro do Condado. As condições construtivas dos edifícios são também a causa dos baixos níveis de conforto térmico, quer no Verão quer no Inverno, e portanto grande obstáculo ao bom aproveitamento passivo de energia (FIGs. 5 e 6). 


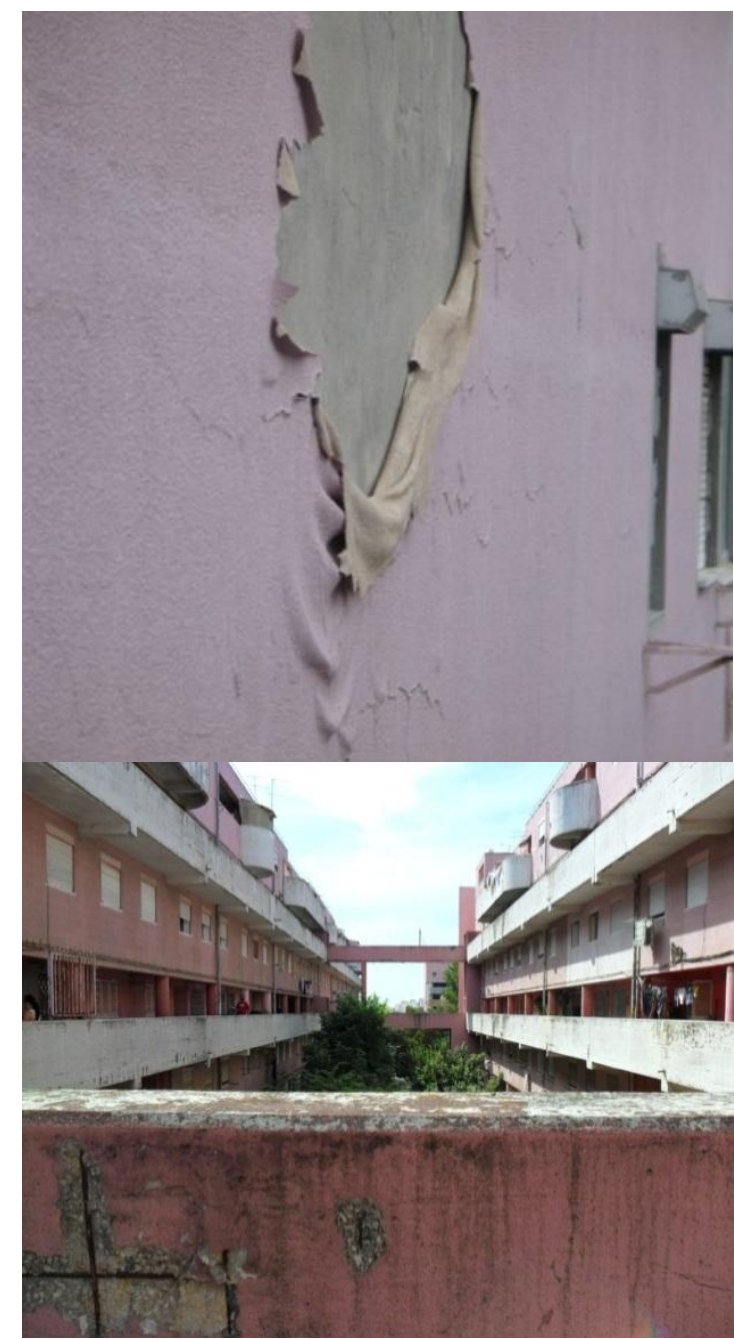

FIGURA 6 - Bairro dos Lóios: Pantera Cor-de-rosa ; Patologias da Construção. (Fotografias dos autores).

\section{Tipo de Construção e Estado de Conservação}

Como referimos no relatório final do Estudo (AA.VV, 2011), os edifícios que compõem o Bairro do Condado foram eregidos segundo o processo de "construção em túnel", muito utilizado nos anos 1980, que apresentava a vantagem de permitir construir paredes e lajes em simultâneo. Este sistema permite rapidez na construção com recurso a pouca mãode-obra especializada, e facilidade de repetições de soluções construtivas, mas, dada a sua rigidez limita e constrange a possível adequação ao uso e a futuras alterações. Segundo Rodrigues,

"a solução estrutural dos edifícios do Bairro do Condado recorre à utilização intensiva do betão armado. O sistema construtivo recorria a betonagens contemporâneas de lajes e paredes, advindo daí o seu nome "cofragem túnel". Esta solução apresenta uma enorme rigidez e monolitismo numa das direções, tipicamente a direção perpendicular à fachada, e grande rigidez na direção perpendicular à anterior, tipicamente longitudinal ao desenvolvimento do edifício." (Rodrigues in AAvv, 2011).

Verifica-se a existência de vãos com dimensões reduzidas resultante do facto de as paredes se constituírem como elementos estruturais. Relativamente aos edifícios que integram este estudo pertencente ao Bairro dos Lóios, estes são construídos com uma estrutura de betão armado, (sistema de pilar e viga), preenchida com alvenaria, de tijolo simples, rebocada e pintada. Nos dois casos, o revestimento das coberturas é assegurado por chapas de fibrocimento. As tubagens encontram-se à vista.

Em termos gerais o conjunto das patologias encontrado na maioria dos edifícios do Bairro do Condado é constituído por delaminação da camada de betão de recobrimento, a consequente exposição das armaduras e a resultante oxidação; descolamento do revestimento do betão; fissuras no betão e nas zonas de junção de elementos pré-fabricados, ou de diferentes materiais; degradação da impermeabilização das coberturas planas; falta de isolante térmico em coberturas e paredes; instalações eléctricas e de telecomunicações exteriores deterioradas e vandalizadas; campainhas, caixas do correio e interruptores removidos ou vandalizados; caixilharias de vãos deterioradas, vandalizadas, e vãos com vidros partidos ou removidos, sistemas de protecção solar dos vãos (estores), partidos ou removidos.

Igualmente $\mathrm{o}$ conjunto dos principais problemas construtivos encontrados nos edifícios do Bairro do Lóios é constituído por oxidação acentuada das armaduras expostas de elementos estruturais em betão armado; degradação dos sistemas de impermeabilização dando origem a infiltrações de águas pluviais; revestimento de paredes com fendilhação

Parc | Unicamp | vol3. n2 | p. 65-84 | Outubro2012 
em diversas zonas; a caixilharia deteriorada e vãos com vidros partidos, instalações elétricas deterioradas e sem manutenção; as paredes exteriores constituídas por um só pano de tijolo provocando fraco desempenho térmico; as coberturas sem isolamento térmico; a fraca promoção da acessibilidade nos edifícios com acesso condicionado para pessoas com a mobilidade reduzida; os espaços comuns de circulação e galerias encerradas devido à falta de segurança; a apropriação de espaços comuns em galerias, patamares e escadas que comprometem as normas de segurança e os acessos às redes de infraestruturas; a escassez de circulações verticais com passagens desbloqueadas para o número de unidades de habitação que servem.

\section{Segurança contra Incêndios e Acessibilidades}

De acordo com o Regulamento de Segurança Contra Incêndios em Edifícios, atualmente em vigor em Portugal, os edifícios dos bairros do Condado e dos Lóios não cumprem com as disposições do mesmo. Nestas condições apenas poderão ser introduzidas alterações no sentido de se diminuir o risco de incêndio e aumentar a segurança das pessoas em situações pontuais onde a estrutura de concepção dos edifícios o permita (FIG. 7).

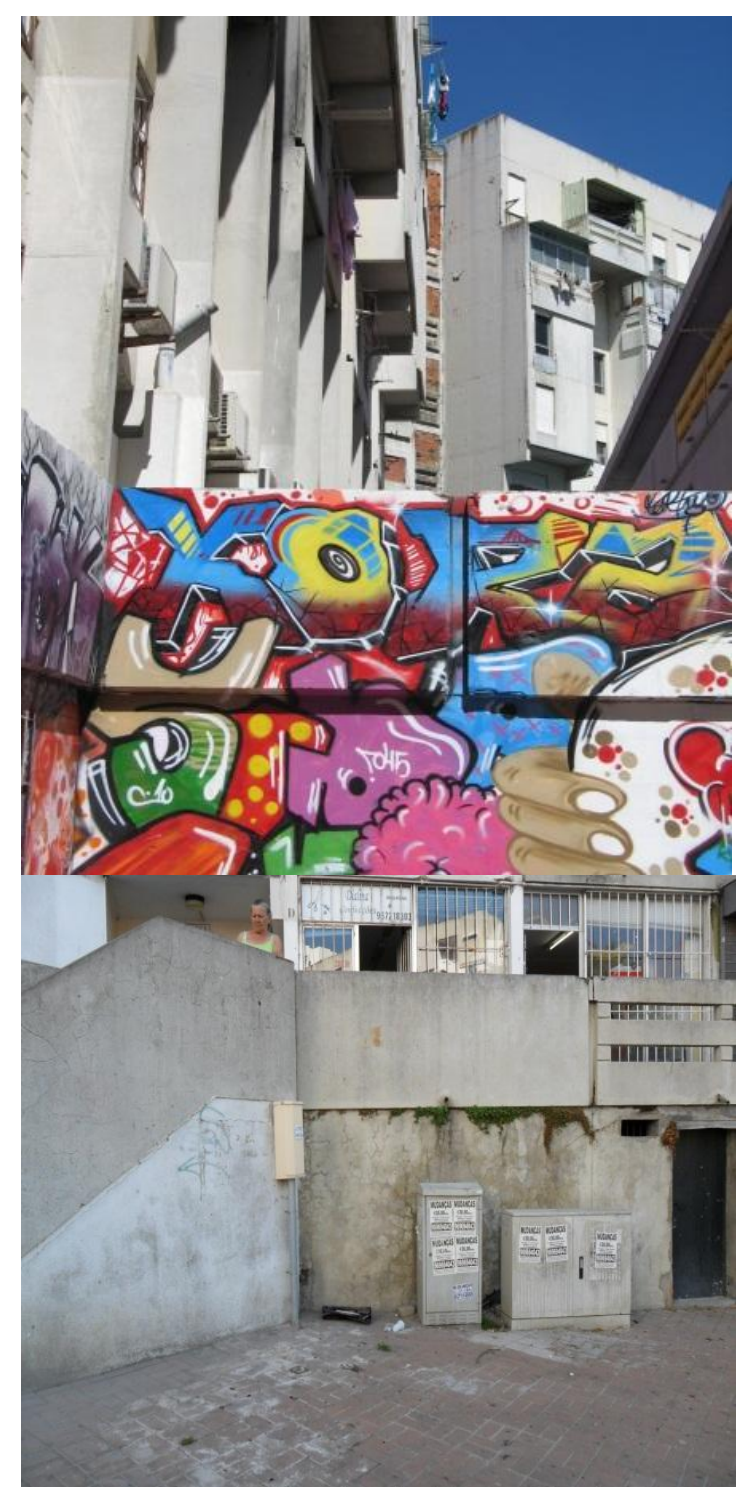

FIGURA 7 - Bairro do Condado: Zona J. (Fotografias dos autores).

Seguidamente apresenta-se uma descrição não exaustiva das anomalias encontradas.

- Distâncias entre módulos de escadas: as distâncias que separam cada módulo de acessos verticais são demasiado grandes. Em ambos os bairros compreendidos pelo estudo verificou-se que a distância entre as unidades habitacionais e o módulo de acessos verticais mais próximo ultrapassa frequentemente a actual distância máxima regulamentar permitida de $15 \mathrm{~m}$. Em várias das unidades funcionais do bairro do Condado verificaram-se valores entre os 46 e os 55 metros, sendo que nas situações excepcionais mais graves atinge os 89 metros. No conjunto do bairro dos Lóios as 
distâncias extra-regulamentares registadas variam entre os 42 e os 82 metros.

. Existências de unidade de habitação em situações de impasse: Existem uma grande quantidade de fogos onde só há uma situação de fuga o que cria situações em que os habitantes em caso de incêndio a meio de uma galeria não encontram outro caminho de fuga alternativo. É o caso de quase todas as unidades funcionais, com excepção das torres e de duas unidades funcionais do Condado.

. Encerramento de espaços comuns $e$ galerias: as circulações comuns $\mathrm{e}$ galerias de acesso aos fogos encontram-se muitas vezes encerradas, muitas delas com chave e acessíveis apenas a alguns moradores, o que impede a saída, da maioria dos moradores, em caso de fuga.

. Apropriação ilegítima de espaços comuns e de circulação: A apropriação ilegítima de espaços comuns e de circulação, em galerias, patamares e lances de escadas compromete as normas regulamentares em vigor no que se refere às questões das acessibilidades dos cidadãos com mobilidade reduzida, às questões de segurança contra incêndios, assim como o acesso às redes (contadores, zonas de corte de abastecimento, etc.).

- Promoção da acessibilidade a pessoas com mobilidade reduzida: tanto nos edifícios, como nos fogos, verifica-se que é reduzida a promoção da acessibilidade, dada a falta de rampas e elevadores. A maioria dos fogos nos dois conjuntos (Condado e Lóios), são acessíveis por meio de galerias tornandose particularmente difícil o acesso aos mesmos. Uma das situações mais gravosas é o caso de uma unidade funcional no Bairro dos Lóios, que tem 7 pisos, 71 unidades habitacionais e 8 lojas e é servida por 2 módulos de circulações verticais (2 escadas), e não tem elevadores.

- Meios de combate contra os incêndios inexistentes, inacessíveis ou danificados: a maioria dos meios de combate contra incêndios encontram-se danificados ou inacessíveis devido a actos de vandalismo, a ocupações indevidas das zonas comuns, ou porque se encontram em zonas de passagem encerradas.

. Existências de grandes saguões nos edificios em torre: No bairro do Condado verifica-se a existência de grandes vazios no interior dos edifícios que ao funcionarem como grandes chaminés, facilitam a propagação do fogo a todo o conjunto edificado. A generalidade dos edifícios onde se verificam essas situações têm 13 a 14 pisos, nos Lóios o edifício em questão tem 14.

. Percurso de fuga com materiais inflamáveis. Nos edifícios analisados, as escadas não se encontram encerradas e, na maioria dos casos não cumprem a largura (em unidades de passagem), para o devido desempenho do percurso de fuga. Não foram identificadas quaisquer portas corta-fogo que impeçam a propagação do fogo entre diferentes áreas, às quais acrescem preocupações relativas à desenfumagem dos espaços, sobretudo nas situações de torre, no Condado, onde o pátio central, nesta matéria, constitui um elemento de assinalável perigo.

As redes dos serviços comuns de eletricidade, comunicações, gás, águas e esgotos encontram-se na generalidade em mau estado de utilização devido fundamentalmente a atos de vandalismo e de falta de conservação e manutenção. Estão neste caso quadros e caixas de colunas de instalações elétricas e de comunicações as quais têm as portas e fechaduras violadas, aparelhos de iluminação de segurança sem funcionarem e aparelhagem de comando deteriorada. No que se refere à rede de incêndios, as bocas-de-incêndio estão de uma forma geral destruídas.

No que se refere às condições exteriores de segurança e acessibilidade, os edifícios não são servidos por vias de acesso adequadas a veículos de socorro em caso de incêndio e dotadas de uma faixa de operação destinada ao estacionamento, manobra e operação destes veículos (FIG. 8). Assim deverão ser previstas vias e faixas de acordo com o antariormente referido. Para além de permitirem o acesso ao edifício através das saídas de evacuação, 
devem servir para facilitar o acesso às fachadas e a entrada directa dos bombeiros, em todos os níveis que os seus meios manuais ou mecânicos atinjam, através de pontos de penetração existentes ou a criar.

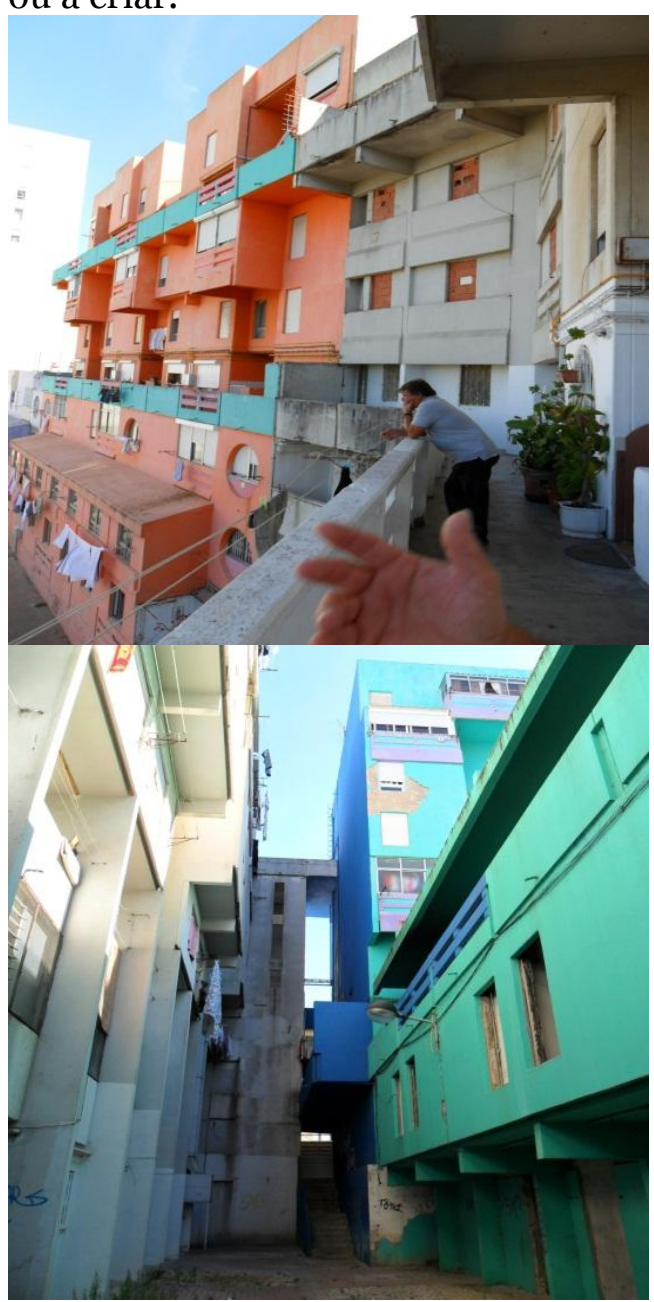

FIGURA 8 - Bairro do Condado: Zona J; Acessibilidades. (Fotografias dos autores).

O fornecimento de água para abastecimento dos veículos de socorro deve ser assegurado por hidrantes exteriores alimentados pela rede de Distribuição Pública ou excepcionalmente por rede privada na falta de condições daquela. Os hidrantes exteriores devem ser instalados junto ao lancil dos passeios que marginam as vias de acesso de forma a que a distância mínima não ultrapasse os 30m de qualquer das saídas dos edifícios que façam parte dos caminhos de evacuação e das bocas de alimentação das redes secas ou húmidas, enquanto existam.

\section{Conforto higrotérmico e eficiência energética}

No que diz respeito às paredes exteriores, e no contexto das exigências da regulamentação em vigor em Portugal, a situação actual no Bairro do Condado pode ser caracterizada por um desempenho térmico de má qualidade. De facto, os valores do coeficiente de transmissão térmica, neste caso, representam $343 \%$ e $376 \%$ do valor de referência, respectivamente para as paredes moldadas e para as paredes em painel pré-fabricado e 133 \% e 146 \% quando a comparação é realizada com o valor máximo admissível, (quadro 1). No caso do Bairro dos Lóios, a situação é um pouco distinta na medida em que uma comparação similar indica valores de discrepância de 246 \% e $200 \%$ (de acordo com o tipo de edifício) em relação ao valor de referência e $96 \%$ e 78 \% em relação ao valor máximo admissível, (quadro 1).

As coberturas, cuja solução construtiva considerada foi idêntica em todos os casos, consubstanciam um problema real de comportamento térmico. A discrepância face ao valor de referência para o Concelho de Lisboa é de $680 \%$ e, face ao valor máximo admissível, de $272 \%$, (quadro 1). Quanto aos envidraçados, pode verificar-se que, do ponto de vista das perdas e ganhos de calor (genericamente considerados por condução), não estão muito desadequados face ao valor de referência regulamentar. No que diz respeito aos ganhos por radiação, as soluções existentes cumprem $\mathrm{o}$ valor mínimo regulamentar. 


\begin{tabular}{|c|c|c|c|c|c|c|}
\hline Elemento construtivo & $\begin{array}{c}\mathrm{U} \\
{\left[\mathrm{W} / \mathrm{m}^{2} \cdot{ }^{\circ} \mathrm{C}\right]}\end{array}$ & $\begin{array}{c}\mathrm{U}_{\mathrm{ref}} \\
{\left[\mathrm{W} / \mathrm{m}^{2} \cdot{ }^{\circ} \mathrm{C}\right]} \\
\end{array}$ & $\begin{array}{c}U_{\max } \\
{\left[\mathrm{W} / \mathrm{m}^{2} \cdot{ }^{\circ} \mathrm{C}\right]}\end{array}$ & $\begin{array}{c}Q_{\text {ext }} \\
{\left[\mathrm{kWh} / \mathrm{m}^{2}\right]}\end{array}$ & $\begin{array}{c}g_{\perp 100 \%} \\
{[-]}\end{array}$ & $\begin{array}{c}g_{\perp 100 \% \text {,máx }} \\
{[-]}\end{array}$ \\
\hline \multicolumn{7}{|l|}{ Bairro do Condado } \\
\hline $\begin{array}{l}\text { Paredes exteriores resistentes da estrutura } \\
\text { laminar }\end{array}$ & 2.40 & 0.70 & 1.80 & 68.66 & - & - \\
\hline $\begin{array}{l}\text { Paredes em painéis pré-fabricados de betão } \\
\text { com agregados de argila expandida }\end{array}$ & 2.63 & 0.70 & 1.80 & 75.25 & - & - \\
\hline Coberturas $\left(\mathrm{U}_{\text {ascendente }}\right)$ & 3.40 & 0.50 & 1.25 & 97.10 & - & - \\
\hline Envidraçados $\left(\cup_{\text {wdn }}\right)$ & 4.10 & 4.30 & - & 117.10 & 0.07 & 0.56 \\
\hline \multicolumn{7}{|l|}{ Bairro dos Lóios, Lote 232} \\
\hline Paredes exteriores (zona corrente) & 1.72 & 0.70 & 1.80 & 48.98 & - & - \\
\hline $\begin{array}{l}\text { Paredes exteriores (zona ponte térmica } \\
\text { plana) }\end{array}$ & 3.70 & 0.70 & 1.80 & 105.78 & - & - \\
\hline Coberturas $\left(\mathrm{U}_{\text {ascendente }}\right)$ & 3.40 & 0.50 & 1.25 & 97.10 & - & - \\
\hline Envidraçados $\left(\cup_{\text {wdn }}\right)$ & 4.10 & 4.30 & - & 117.10 & 0.49 & 0.56 \\
\hline \multicolumn{7}{|l|}{ Bairro dos Lóios, edifícios “Pantera” } \\
\hline Paredes exteriores (zona corrente) & 1.40 & 0.70 & 1.80 & 40.05 & - & - \\
\hline $\begin{array}{l}\text { Paredes exteriores (zona ponte térmica } \\
\text { plana) }\end{array}$ & 3.41 & 0.70 & 1.80 & 97.45 & - & - \\
\hline Coberturas $\left(\mathrm{U}_{\text {ascendente }}\right)$ & 3.40 & 0.50 & 1.25 & 97.10 & - & - \\
\hline Envidraçados $\left(\cup_{\text {wdn }}\right)$ & 4.10 & 4.30 & - & 117.10 & 0.07 & 0.56 \\
\hline
\end{tabular}

U - Coeficiente de transmissão térmica da solução construtiva

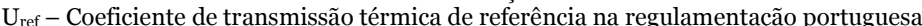

$U_{\text {máx }}$ - Coeficiente de transmissão térmica máximo admissível na regulamentação portuguesa

Qext - Perdas de calor unitárias

$\mathrm{g}_{\perp 100 \%}$ - Factor solar da solução existente, com protecção activa

$\mathrm{g}_{\perp 100 \% \text {,máx }}$ - Factor solar, com protecção activa, máximo admissível na regulamentação portuguesa

Quadro 1 - Valores relativos à transmissão de calor

A comparação da caracterização térmica da envolvente com as disposições regulamentares fornece indicações pertinentes quanto a uma análise de base. Deve no entanto considerar-se que, se do ponto de vista dos valores de referência, a regulamentação portuguesa em vigor (RCCTE, publicada em 2006) parece razoavelmente adequada, já do ponto de vista dos valores máximos admissíveis, pode afirmar-se que o RCCTE é muito permissivo.

Considera-se portanto que as soluções construtivas existentes no Bairro do Condado contribuem para um potencial de desconforto térmico muito significativo ou, de outro modo, que exigem um grande consumo de energia para a obtenção das condições de conforto nominais. No caso do Bairro dos Lóios, a situação existente das paredes exteriores é menos gravosa do que a do Bairro do Condado, embora se possa afirmar que é claramente desajustada face aos actuais padrões de conforto térmico em edifícios de habitação. As coberturas, como acima referido, carecem claramente de uma intervenção de reabilitação com o objectivo de reduzir a transmissão de calor e, por esta via, proporcionar melhores condições de conforto interior. Note-se que uma cobertura é o elemento construtivo mais exposto à radiação solar, em termos anuais e sobretudo na estação de arrefecimento (Verão), o que obriga a um cuidado acrescido face ao seu comportamento térmico. A não ser assim, a obtenção de condições de conforto térmico de Verão fica comprometida, especialmente em habitações destinadas a populações com baixo rendimento.

Finalmente, importa ainda considerar que o estudo efectuado não

considerou a permeabilidade ao ar dos envidraçados. Tendo em conta o tipo de caixilharia e de vidro, bem como a época e o tipo de construção, pode afirmar-se 
que o sistema de envidraçados existentes não tem uma permeabilidade ao ar adequada, dando assim origem a infiltrações de ar não controladas que dificultam a obtenção de condições de conforto. Por esta razão, mas também considerando o seu valor de coeficiente de transmissão térmica, considera-se que os envidraçados existentes não respondem de forma adequada às exigências de conforto.

Com base no trabalho agora realizado, recomenda-se que a reabilitação futura nestes bairros inclua uma intervenção nas coberturas, com a aplicação de isolante térmico em camada com espessura nunca inferior a $80 \mathrm{~mm}$ e uma intervenção nas fachadas de acordo com uma solução construtiva que englobe isolante térmico. Considera-se mais adequada uma solução de reabilitação de fachada com colocação de isolante térmico pelo exterior de forma a potenciar a utilização da inércia térmica interior existente nalguns casos. A instalação de novos envidraçados não parece assumir um papel determinante, no contexto das simulações realizadas, embora se deva referir que os benefícios resultantes seriam decerto importantes para a melhoria do conforto térmico. Por outro lado, novos envidraçados permitiriam uma melhoria significativa na obtenção de conforto acústico.

Importa ainda referir que o sucesso futuro das condições de conforto higrotérmico, bem como uma melhoria da eficiência energética nestes edifícios, estão muito condicionados por padrões de utilização adequados. Considera-se assim determinante a promoção de manuais de utilização das habitações, acompanhados de acções de informação e sensibilização que permitam aos habitantes saber como melhorar o conforto nas suas habitações.

A idade, a falta de manutenção e limpeza dos edifícios, a má utilização do espaço, os actos de vandalismo, quer nas áreas comuns dos edifícios, quer no espaço urbano que lhes está adjacente, contribuem gravemente para a degradação dos conjuntos.

\section{Algumas conclusões sobre o diagnóstico}

$\mathrm{Na}$ sua actual forma os edifícios são "inadministráveis" ou se preferirmos "ingovernáveis". Esta situação decorre da deficiente definição dos limites dos lotes, da continuidade dos espaços de circulação entre lotes e da partilha das circulações verticais com situações de impasse de largas dezenas de metros, facilitando processos de apropriação ilegal das mesmas. A idade, a falta de manutenção e limpeza dos edifícios, a má utilização do espaço, os atos de vandalismo, quer nas áreas comuns dos edifícios, quer no espaço urbano que lhes está adjacente, contribuem gravemente para a degradação dos conjuntos.

$O$ esquema funcional destes edifícios, na maior parte dos casos dificulta a leitura dos mesmos, verificando-se situações complexas, anárquicas, e por vezes, labirínticas, na forma como as circulações se distribuem no seu interior. As áreas de circulação comum são as áreas que intermedeiam o domínio público e o domínio privado, assumindo uma importância singular, uma vez que são o primeiro espaço de contacto entre visitantes e visitados. Deste modo, constituem-se como o espaço de controlo dos acessos e do estabelecimento de relações de vizinhança.

Nos bairros em causa, os acessos aos lotes raramente são verdadeiramente controlados, principalmente devido ao mau funcionamento dos trincos ou à ausência de campainhas, o que leva a que a "porta da rua" esteja por regra aberta, tornando o espaço de hall num contínuo do espaço público que só parece acabar nos controlos de apropriação "ilegal" das galerias, ou na própria porta de casa.

A apropriação de espaços de circulação, quer seja pela necessidade de criar fronteiras (controlo de acesso), de forma a intermediar o espaço público e privado e aumentar a sensação de segurança dos habitantes, quer seja pela necessidade de colmatar uma carência espacial do fogo, assume consequências 
negativas e positivas que importa salvaguardar.

Se por um lado temos os aspectos negativos decorrentes da instalação de controlos, como a multiplicação de obstáculos à circulação de pessoas de mobilidade reduzida e à circulação em caso de necessidade de fuga, por outro temos o estabelecimento de relações de pertença com o espaço de circulação comum que, naturalmente, resulta na manutenção desses mesmos espaços. Seria expectável que esta constituísse a principal preocupação em matéria de segurança em caso de fuga. Mas estes os já referidos obstáculos nos circuitos de fuga e o encerramento de circulações verticais (ou das suas saídas para a rua) - correspondem apenas a um acréscimo de preocupação face à ausência de manutenção dos meios de combate a incêndios (quando estes existem) e sobretudo face ao próprio desenho dos edifícios. Como referimos anteriormente, na maioria dos casos os percursos de fuga não se encontram dimensionados de acordo com as unidades de passagem indicadas na regulamentação actual, nem as situações de impasse cumprem as distâncias desejáveis às circulações verticais.

Ainda, sobretudo no Condado, há que registar a partilha dos mesmos acessos, e das mesmas circulações com usos diferenciados (habitação, serviços e equipamentos), numa fórmula de distribuição de funções pouco convencional. Estas circulações, para maior conforto e permeabilidade desejável, deveriam ser separadas e a sua leitura clarificada.

Em contrapartida, a nível urbano, há que reconhecer e salutar a convivência de usos registada nos conjuntos urbanos em estudo; é que a alternativa - formações urbanas mono funcionais - tem por norma um impacto negativo na qualidade de vida dos seus habitantes, especialmente àqueles que não se deslocando ao emprego, continuamente o habitam: os desempregados, as donas-de-casa, os que trabalham a partir de casa, as crianças, os adolescentes, os idosos, etc.,
(Montaner, 2006: 34). O que está em causa não é apenas a qualidade de vida dos habitantes ou a valorização programática e patrimonial do bairro, é também a produção de emprego, economia, e cultura nas áreas residenciais. A presença de diferentes valências no espaço residencial é garante de vitalidade urbana e os conjuntos urbanos em estudo comprovam-no.

Enquanto edifícios de habitação social, e portanto, instrumentos de apoio a um período de insolvência das famílias para reestruturação das suas vidas, dos seus projectos e das suas responsabilidades cívicas, trata-se de edifícios onde há que criar melhores condições de habitabilidade não recorrendo a soluções que impliquem gastos por parte dos seus habitantes mas a partir de alternativas decorrentes da rentabilização dos próprios edifícios, ou seja, trazendo à evidência a capacidade de resposta de cada edifício, abrindo-se caminho para o desenvolvimento do seu potencial, mesmo que, com outros níveis ou tipos de ocupação.

\section{Cenários de intervenção}

Após a caracterização e diagnóstico do estado físico e funcional dos edifícios onde foram localizados os problemas detectados e identificadas as questões relacionadas com a gestão dos edifícios, assim como as principais carências dos conjuntos urbanos onde os lotes se inserem, procedeu-se, no estudo realizado, à elaboração do quadro de cenários possíveis para o futuro dos bairros, que serve de apoio à decisão e de suporte a uma possível reabilitação urbana (AA.vv. 2011: 6. Cenários de Intervenção).

Se por um lado se pretendem respostas concretas e objectivas, que suportem uma reabilitação equilibrada e sustentada dos lotes que integram o conjunto e a sua envolvente próxima de forma a melhorar a qualidade de vida dos seus moradores, por outro pretendese obter um número variado de possibilidades de intervenção de acordo com o interesse e as características 
específicas de cada lote. Desta forma, os cenários possíveis não são considerados conjuntos de acções estanques e herméticas em si mesmas, mas uma série de linhas de actuação combináveis e reorganizáveis, onde as diversas acções se contabilizam individualmente e se podem realizar através de diversas combinações. Neste sentido, foram realizados quadros indicando várias acções (AA.vv. 2011: 6. Cenários de Intervenção), tendo os mesmos, um carácter operativo através da combinação das diferentes acções permitindo organizar dados, prever soluções, definir custos e antever benefícios de acordo com o interesse de quem as promove.

Os cenários de intervenção delineados têm por base o diagnóstico (AA.vv. 2011: 5. Diagnóstico). Neste, haviam sido introduzidas uma série de linhas de investigação (questões) que desde logo ganharam um carácter propositivo, pondo à prova a identificação de elementos de valorização patrimonial contemporâneos, a promoção da melhoria ambiental dos conjuntos e a aproximação ao funcionamento padrão da cidade convencional.

Procurou-se responder à seguinte questão: "quais as soluções tipológicas e construtivas contemporâneas que respondem aos desejos dos moradores, às actuais normas e regulamentos da edificação, e que ainda assim ressalvem os pressupostos do projecto original, sempre que a estes corresponda uma qualidade inequívoca e a própria identidade do bairro?" Apesar da resposta não possuir exactidão matemática, fornece um conjunto de ponderações de apoio à decisão. Materializámos, portanto, esse conjunto de ponderações sob a forma de cenários que, colocados lado a lado, põem em evidência a relação custo / benefício das diferentes acções.

Foram considerados quatro cenários. O cenário A - "Manter a situação existente", o cenário B "Reparações", o cenário C "Intervenção", e o cenário D - "Nova Chelas".
O cenário A corresponde a "manter a situação existente" e implica não fazer qualquer tipo de intervenção. Este cenário tem custos associados: os custos decorrentes da manutenção e gestão do edificado existente, os custos correntes energéticos associados à falta de qualidade construtiva, e os custos indemnizatórios e políticos em caso de catástrofe com perca de vidas humanas ou prejuízo da integridade física dos moradores (que neste cenário seriam mais elevados do que outros), assim como os custos políticos associados à manutenção dos moradores sem melhorias da sua qualidade de vida urbana. Não existem quaisquer benefícios assinaláveis, mantendo-se todas as lacunas, deficiências e condicionantes já assinaladas no diagnóstico.

O cenário $\mathrm{B}$, apelidado de "Reparações", corresponde à assunção de uma organização decorrente da apropriação feita pelos moradores, a qual reproduz um modelo de autogestão por "unidade funcional"vi. $\mathrm{O}$ que se procura neste cenário é trazer as condições necessárias ao funcionamento das unidades funcionais, através da introdução de escadas de emergência, reparação ou substituição de elevadores (se for o caso), substituição das redes (organizadas agora por unidade funcional), reparação das áreas comuns de circulação, instalação de sistemas de combate a incêndios, reparação de patologias, reparação de coberturas e pintura das fachadas. Os benefícios das acções descritas neste cenário correspondem sobretudo à redução dos riscos associados a catástrofes e a uma pequena melhoria dos níveis de conforto, sendo questionáveis os benefícios ao nível da gestão das unidades funcionais com mais do que um lote. Estas unidades funcionais têm os limites das áreas comuns que os habitantes conseguiram garantir e são, exclusivamente, o resultado do desejo de segurança contra o furto, ao invés de um projecto colectivo de gestão do património comum.

$\mathrm{O}$ cenário $\mathrm{C}$, apelidado de "Intervenção", corresponde a um cenário 
cuja implementação tem como principal objectivo criar as condições para o funcionamento do edificado construtivo lote a lote, através da segmentação das áreas comuns por lote, resultando numa melhoria da qualidade da construção, das condições ambientais e da produtividade.

No capítulo da melhoria da qualidade construtiva foram consideradas as seguintes acções: reparação de patologias, instalação de segundo pano de fachada e sistema de cobertura com isolamento térmico e impermeabilização integrados, substituição de caixilharia existente por caixilharia com corte térmico e vidro duplo e, quando necessário, reforço estrutural; garantindo-se, desta forma, benefícios ao nível da melhoria dos níveis de conforto e dos níveis de aproveitamento passivo de energia. Destas acções resultariam, para além da poupança efectiva e quotidiana no que diz respeito ao desgaste e utilização do edifício, a redução de ocorrências de patologias construtivas e de riscos associados a sismos e outras catástrofes.

No que se refere à produtividade foram consideradas a instalação de colectores solares para aquecimento de águas, sistema de aproveitamento de águas pluviais e instalação de painéis foto-voltaicos, garantindo-se, desta forma, os benefícios de poupança e aproveitamento activo de energia, e a possibilidade de rentabilização através da venda de energia à rede. Há contudo que ter em atenção que o sucesso deste tipo de intervenção, com recurso a tecnologias activas de captação de energia renovável, depende fortemente do modelo de governação que venha a ser adoptado. De facto, há que definir todo o conjunto de questões relacionadas com a aquisição, manutenção e gestão dos sistemas, do que depende uma estrutura de propriedade claramente definida e assumida pelos moradores e pelas entidades responsáveis pela gestão dos imóveis.

$\mathrm{O}$ cenário $\mathrm{C}$ obrigou a alguma investigação em desenho, ou esquema gráfico, de modo a afirmar as pretensões do ideal proposto, uma vez que diferentes tipologias funcionais obrigam a diferentes formas de intervençãovii. Foram consideradas três tipologias funcionais para investigação gráfica: a "Banda do Condado", a "Torre do Condado" e a "Banda dos Lóios", sendo aqui apresentada aquela que revela mais problemas quanto à acessibilidade e manutenção do edifício.

A "Banda do Condado" é caracterizada pela partilha dos elementos de circulação vertical por diferentes lotes (no caso três lotes, FIG.10). A sua segmentação, de forma a possibilitar um funcionamento mais próximo do padrão da cidade convencional, está condicionada à criação de acessos verticais por lote, à substituição de redes (organizadas também por lote), à reparação das áreas comuns de circulação e à demolição da circulação vertical existente, devendo também ser considerada a instalação de sistemas de combate a incêndio. A criação de acessos verticais por lote tem a dupla função de organizar os limites administrativos e, simultaneamente, reduzir a dimensão dos impasses e percursos de fuga. 


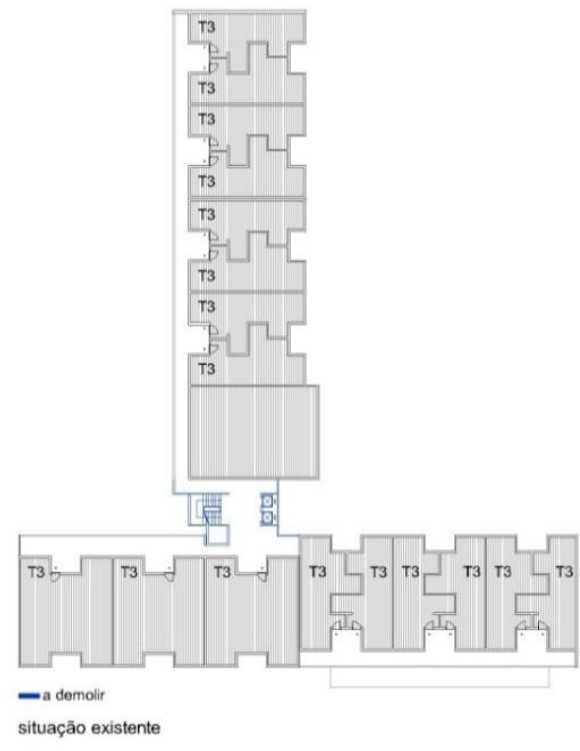

No caso da "Torre do Condado" (FIG. 11), trata-se de um edifício que, por norma, funciona sem quaisquer dependências de outros lotes (tendo em alguns casos registado alienações de propriedade). O principal problema para o bom funcionamento das torres prendese com a segurança contra incêndios. Em caso de incêndio, a existência de um saguão central no interior da torre, funciona como uma "chaminé" e, neste sentido, a ausência de uma escada

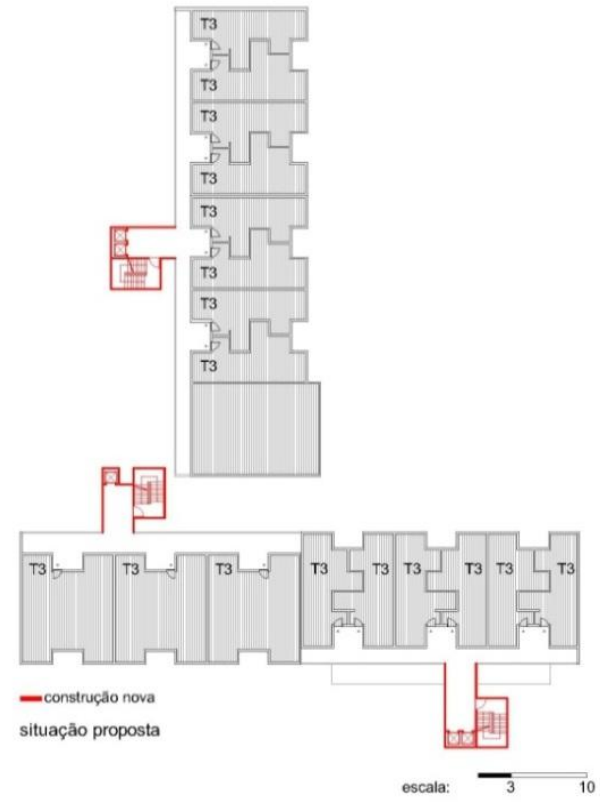

FIGURA 9 - Esquema gráfico para a tipologia funcional: Banda do Condado, "Zona J".

encerrada para percurso de fuga é um aspecto de maior preocupação, sobretudo face ao elevado número de habitantes que cada torre comporta.

Assim sendo, estudou-se a hipótese de encerramento de uma das escadas, recorrendo à alteração do acesso de um fogo por piso. Acção que deve ser considerada a par com a necessária reparação das áreas comuns de circulação e com a reparação/instalação dos sistemas de combate a incêndios.

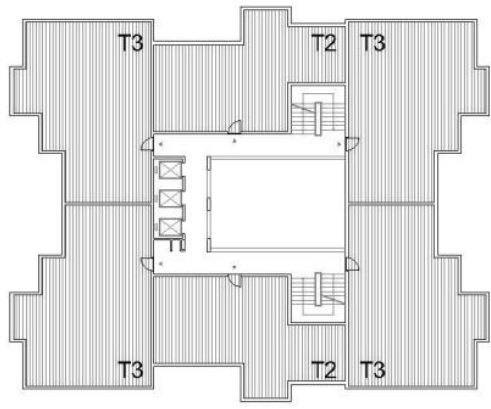

situação existente

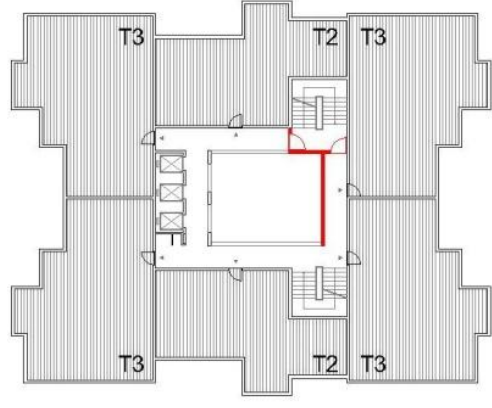

- construção nova situação proposta

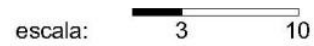

FIGURA 10 - Esquema gráfico para a tipologia funcional: Torre do Condado, “Zona J”. 
No caso dos Lóios, a sistematização de soluções torna-se mais complexa, dadas as particularidades dos edifícios estudados. Foi, a título de exemplo, considerado o estudo da "Banda dos Lóios" correspondente aos lotes adjacentes à rua ajardinada do conjunto da "Pantera Cor-de-Rosa" (FIG. 12). Neste, a segmentação lote a lote encontra-se bastante condicionada pela forma do conjunto, tendo sido a divisão dos lotes em unidades funcionais demonstrativa da impossibilidade de funcionamento dos lotes de acordo com os limites instituídos.

\section{Consideramos}

portanto recomendável que, quer no cenário $\mathrm{B}$, quer no cenário $\mathrm{C}$, qualquer intervenção seja global. Provavelmente será de considerar a renomeação e organização dos lotes em função dos acessos verticais que forem possíveis edificar, e que, conforme o sugerido para a banda do Condado, tenham também a dupla função de organizar os limites administrativos e reduzir o comprimento dos impasses e percursos de fuga. Deverão ainda ser consideradas a reparação das áreas comuns de circulação e a reparação/instalação dos sistemas de combate a incêndios.
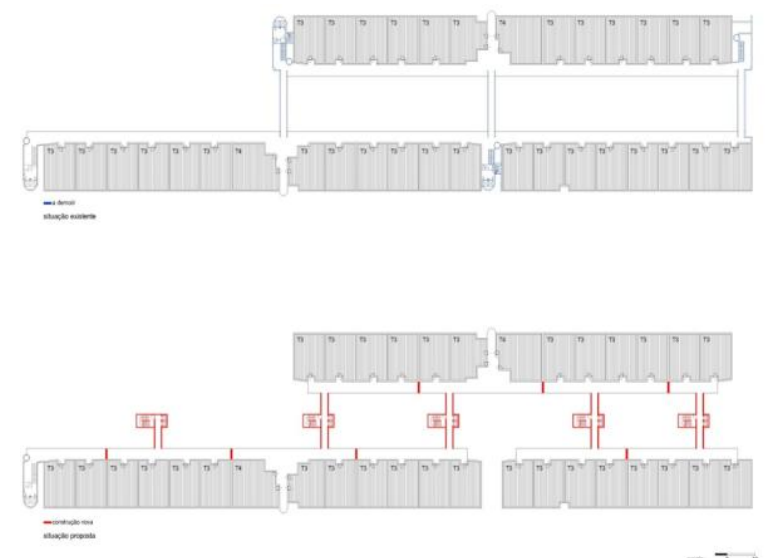

FIGURA 11 - Esquema gráfico para a tipologia funcional: banda dos Lóios, "Pantera Cor-derosa”.

\section{Conclusão: reflexões sobre desenvolvimentos futuros}

Os esquemas gráficos apresentados, por permitirem alterações da organização do edificado, deveriam também permitir as alterações de fundo que garantissem uma gestão mais próxima do padrão da cidade convencional. Para tal, importa esclarecer a propriedade dos lotes, definindo e simplificando as responsabilidades de gestão. A partir destes modelos é ainda possível alterar a estrutura organizativa dos lotes. A sua actual forma, para além de ser de difícil gestão, tem ainda alguma mistura funcional, resultante da ocupação de alguns pisos com serviços, sem a salvaguarda de circulações e acessos diferenciados. A natureza das ocupações (habitacional e de serviços) acentua a questão acima referida; e portanto, a possibilidade de reordenar essa ocupação por lote, deslocando os escritórios para os lotes menores (com dois pisos além do térreo). Esta solução resolveria as incompatibilidades descritas, potenciando a alienação de propriedade (privatização) e a implantação de modelos de gestão apropriados a cada tipo de ocupação, por lote. A alienação seria assim uma oportunidade de reduzir os custos correntes das instituições (IHRU, CML e GEBALIS), no que se refere aos edifícios que lhes pertencem. Na prática, essa redução de custos é pouco significativa enquanto houver propriedade pública nos lotes. Neste sentido, a alteração dos princípios (ou regulamentos) de gestão, permitiria mudar essa realidade. Se a alienação for um objectivo, fará sentido adoptar políticas que permitam e potenciem a venda (e portanto valorização) de fracções no mercado convencional.

A resposta que encontramos para a resolução de muitos dos problemas com que fomos confrontados passa pela aproximação dos conjuntos edificados à forma de funcionamento da cidade convencional. A criação de acessos verticais por lote tem, como funções essenciais, organizar os limites administrativos dos conjuntos, reduzir a dimensão dos impasses e percursos de fuga, facilitar a vigilância, a segurança e a gestão dos lotes e potenciar a alienação através da privatização das fracções. Esta última tarefa facilitaria a futura venda 
das fracções, potenciando maior encaixe financeiro decorrente da venda a preços competitivos, para além dos benefícios advindos do "mix social" mais heterogéneo de moradores nos bairros. Um factor que importa referir prende-se com o facto de termos construído cenários com várias entradas permitindo uma implementação dos trabalhos realista, de acordo com as necessidades e com as possibilidades dos autores.

\section{Referências}

AA.VV. (2006). Operação Cova da Moura, Iniciativa Operação de Qualificação e inserção Urbana em Bairros Críticos Volume I - Diagnóstico. Malheiros, Jorge, (coord. geral), Lisboa.

AA.VV. (2006b). Iniciativa Bairros Críticos, Operação Vale da Amoreira, Diagnóstico. Vale da Amoreira: GAT.

AA.VV. (2008). Contributos para o Plano Estratégico de Habitação 2008/2013 Documento Políticas Urbanas. Lisboa: CET/ISCTE. Disponível em: http://habitacao.cm-lisboa.pt/documentos /123421120oI5eGS7kj9Fq51IF7.pdf. Acesso em: Jan. 2011.

AA.VV. (s.d.). Operação Lagarteiro. Lagarteiro - Uma intervenção alicerçada na participação. Marques, Teresa Sá (coord.) Lisboa.

AA.VV. (2011). Relatório Final. Estudo de Avaliação e Diagnóstico das Necessidades de Intervenção em Edifícios nos Bairros do Condado e dos Lóios em Marvila. SILVA, Teresa Madeira da (coord.), (Texto policopiado).Lisboa: ISCTE-IUL.

ALVES COSTA, Alexandre (2001). Excertos de Escritos Dispersos dos Anos 80. J-A Jornal Arquitectos. 200, p. 36.

ALVES, Pedro Marques, (2009). "Uma" casa portuguesa? Formas de Habitar Contemporâneas e a Capacidade de Respostas dos Modelos de Habitação Colectiva Existentes, o seu Papel nos Processos de Transformação Urbana, Trabalho Final do Mestrado Integrado em Arquitetura (Texto policopiado). Lisboa: ISCTE-IUL.
ASCHER, François (2010). Novos Princípios do Urbanismo. Seguidos dos Novos Compromissos Urbanos. Um Léxico. Lisboa: Livros Horizonte.

CABRITA, A.M. Reis (1981). Conjunto habitacional em Chelas: Zona 2. Revista Arquitectura, Lisboa: S. 4, n. 140, pp. 19-29.

CML, Câmara Municipal de Lisboa, Programa Local de Habitação de Lisboa (2010). Carta dos BIP/ZIP Bairro e Zonas de Intervenção Prioritária de Lisboa, Relatório, Metodologia de Identificação e Construção da Carta dos BIP/ZIP, Disponível em: http://www.cmlisboa.pt/archive/doc/o6_Re latorio_Metodologiade_identificacao_e_con strucao_da_Carta_dos_BIP-

ZIP_14_de_Julho_.pdf.

CML, Câmara Municipal de Lisboa, DMCRU - Unidade de Projecto de Chelas, IHRU - Instituto da Habitação e Reabilitação Urbana, (2008). Programa de Reabilitação e Desenvolvimento Integrado de Marvila Documento Estratégico, A Situação de Referência, Lisboa: IHRU - Instituto da Habitação e Reabilitação Urbana.

FERRÃO, João, (2003). "Intervir na cidade: complexidade, visão e rumo", Portas, Nuno; Domingues, Álvaro; CABRAL, João (org.) Políticas Urbanas: Tendências, estratégias e oportunidades. Lisboa: Fundação Calouste Gulbenkian, pp. 219-225.

HEITOR, Teresa Valsassina, (2001). A Vulnerabilidade do Espaço em Chelas. Uma abordagem Sintáctica, Lisboa: FCG e FCT.

LAPUERTA, José Maria de; ALTOZANO, Fernando, (2010). Vivenda, Envolvente, Hueco - Un Catálogo de Soluciones Construtivas para la Vivenda. Madrid: Actar.

LNEC, Ministério das Obras Públicas, Transportes e Habitação, (2003). Parecer sobre anomalias nos revestimentos de fachada do bairro do Condado, em Chelas. Relatório 151/o3 - NRI. Lisboa: LNEC.

LNEC (2008), Colaboração do LNEC na Análise das Condições de Habitabilidade do Edificado no Bairro do Alto da Cova da Moura. Avaliação das Necessidades de Reabilitação do Edificado. Relatório Síntese. Lisboa: LNEC. 
MONTANER, Josep Maria; MARTINEZ, Zaida Muxí, (2006). Habitar el Presente. Vivenda em España: Sociedad, Ciudad, Tecnología y Recursos. Madrid: Ministerio de Vivienda.

MONTEYS, Xavier; Fuertes, Pere, (2001). Casa collage: un ensayo sobre la arquitectura de la casa, Barcelona: Editorial Gustavo Gilli, p. 112.

IHRU, Instituto da Habitação e Reabilitação Urbana, (s.d.), Portal da Habitação, Disponível em: http://www.portaldahabitacao.pt/pt/portal/ glossario/. Acesso em Jan. 2011.

PEREIRA, Luz Valente; Gago, M. Amélia Corrêa; e, Lopes, M. José, (1984), Inquérito à Habitação Urbana. Lisboa: LNEC.

PORTAS, Nuno, (2005). Arquitectura (s) Teoria e Desenho, Investigação e Projecto. Porto: FAUP Publicações.

PORTAS, Nuno; Domingues, Álvaro; Cabral, João, (2003). Políticas Urbanas: Tendências, estratégias e oportunidades, Lisboa: Fundação Calouste Gulbenkian.

RODRIGUES, Fernando. (2011). Estruturas e estado de conservação. in AA.VV. (2011). Relatório Final. Estudo de Avaliação e Diagnóstico das Necessidades de Intervenção em Edifícios nos Bairros do Condado e dos Lóios em Marvila. SILVA, Teresa Madeira da (coord.), (Texto policopiado). Lisboa: ISCTE-IUL.

SILVA, Christopher; PEREIRA, David; LEITE, Gonçalo; VIEIRA, Liliana; RIBEIRO, Luís, (2009). CHELAS: Zona N2 Byrne e Reis Cabrita O "Pantera Cor-deRosa". Trabalho de História da Arquitectura Portuguesa, $5^{\circ}$ ANO, 08/o9, Lisboa: ISCTE.

SILVA, J. Mendes da; ABRANTES, Vitor; Patologia em Paredes de Alvenaria. In Seminário sobre Paredes de Alvenaria. P.B. Lourenço et al. (eds), 2007, p. 65-84. Disponível em: www.civil.uminho.pt/alvenaria/docs/o65_o 84.pdf. Acesso Junho 2012.

SILVA, Teresa Madeira; ALVES, Pedro Marques, OLIVEIRA, Maria João; MAGALHÃES, Miguel; (2011). Organização do Espaço em Edifícios de Habitação Social: Conflitualidade e Insegurança Urbana, in SICYUrb, Second International Conferece of
Young Urban Researches. Lisboa: ISCTEIUL. Disponível em: http://conferencias.cies.iscte.pt /index.php/icyurb/sicyurb/paper/view /253/101. Acesso em: Junho 2012.

SILVA, Teresa Madeira da; ALVES, Pedro Marques; MAGALHÃES Miguel Vasconcelos; OLIVEIRA, Maria João; (2011). Edifícios de Habitação Social: Diagnóstico e Cenários de Intervenção, in CIDADES, Comunidades e Territórios. No 22, (Junho 2011). pp. 82-98. ISSN: 2182-3030. Disponível em: http://cidades.dinamiacet.iscte-iul.pt. Acesso em Maio 2012.

\section{Notas}

'Em artigo congénere - Edifícios de
Habitação Social: Diagnóstico e Cenários de
Intervenção, in CIDADES, Comunidades e
Territórios. No 22, Junho 2011. pp. 82-98,
abordou-se a mesma temática geral, no
entanto, aqui o enfoque centra-se nas
questões das tipologias funcionais do
conjunto e nas patologias da construção.

ii Equipa: Arquitetura: Teresa Madeira da Silva, Pedro Marques Alves, Miguel Vasconcelos Magalhães, Maria João Oliveira. Colaborador: Samuel Dias. Consultores: Pedro Viana Botelho e Pedro Mendes. Fundações e Estruturas: Fernando Rodrigues. Gestão Energética: Vasco Moreira Rato. Redes e Segurança Integrada: Joaquim Nogueira. Economia, Gestão Urbana e Gestão do Património: Pedro Costa. Coordenação: Teresa Madeira da Silva.

iii Ver bibliografia: AA.VV. (2011), Relatório Final. Estudo de Avaliação e Diagnóstico das Necessidades de Intervenção em Edifícios nos Bairros do Condado e dos Lóios em Marvila. Lisboa: ISCTE-IUL.

\footnotetext{
iv Realizaram-se, nesta fase, reuniões com os agentes e parceiros locais, nomeadamente com os serviços do Gabinete do Bairro do Condado (da GEBALISiv), com a Junta de Freguesia de Marvila (Pelouro da Habitação), com Polícia de Segurança Pública (Agentes de Proximidade), com a Associação de Moradores do Condado, com o Centro de Desenvolvimento Comunitário e
} 
Social do Bairro dos Lóios (Associação

Tempo de Mudar), com a Santa Casa

Misericórdia de Lisboa, entre outros.

v Ver 5.2.1. Fichas de diagnóstico do bairro do Condado e 5.2.2. Fichas de diagnóstico do bairro dos Lóios. In AA.VV. (2011), Relatório Final. Estudo de Avaliação e Diagnóstico das Necessidades de Intervenção em Edifícios nos Bairros do Condado e dos Lóios em Marvila. Lisboa: ISCTE-IUL.

vi Como referimos, a "Unidade funcional" é um conjunto de lotes que partilham dependências essenciais ao funcionamento dos edifícios, nomeadamente caixas de escadas, elevadores, redes de água, esgotos, eletricidade e gás.

vii Os esquemas gráficos apresentados não são de modo nenhum proposta de projecto para os edificios em causa, mas antes, esquemas desenhados que sugerem soluções funcionais passíveis de serem trabalhadas pelos projectistas.

Cada torre comporta entre 42 a 44 fogos. 